\title{
MENYEMBAH TUHAN: SUATU STUDI EXEGETIS MAZMUR 100 ${ }^{1}$
}

\author{
Gustav R. Rame
}

\section{PENDAHULUAN}

Menyembah Tuhan merupakan ekpsresi iman tetapi juga merupakan ketergantungan sepenuhnya kepada Allah. Mazmur 100 adalah salah satu dari sekian banyak Mazmur yang mengungkapkan hal ini. Bahwa menyembah TUHAN tidak hanya dilakukan oleh pribadi-pribadi tertentu sebagai pameran kerohanian, tetapi menyembah TUHAN terjadi ketika individu-individu, kelompok tertentu telah merasakan kasih Allah yang memelihara mereka. Penyembahan dilakukan baik secara pribadi, kelompok, atau kumpulan masa dengan suara nyanyian yang penuh sukacita.

Dalam usaha menyelami makna menyembah TUHAN dalam Mazmur 100, penulis mendekati teks dengan pola pendekatan "ANALISA BENTUK" dengan empat kerangka utamanya yakni:

1. Menentukan struktur teks

2. Menentukan bentuk literatur (genre) teks

3. Kedudukan kehidupan teks

4. Menentukan tujuan dan fungsi teks

Baru kemudian ditindaklanjuti dengan eksegese terhadap teks. Uraian ini belum secara komprehensif membahas makna menyembah TUHAN dalam Mazmur 100. Namun kiranya dapat menjadi stimulan awal dalam mengembangkan teknik-teknik penafsiran terhadap teks-teks Perjanjian Lama dengan metode "ANALISA BENTUK."

\section{ANALISA BENTUK MAZMUR 100:1-5}

\section{A. Struktur Mazmur 100:1-5}

Mazmur 100:1-5 dapat dibagi menjadi 3 bagian, yaitu bagian A (ay. 2, 4), bagian B (ay. 3), bagian C (ay. 5). Sedangkan secara khusus, ayat 1 merupakan judul dan pendahuluan dari Mazmur 100:1-5 ini.

Beberapa patokan yang menjadi alasan pembagian Mazmur 100:1-5

$1 \quad$ Tulisan ini pernah dimuat di majalah "Pelangi" (majalah Alumni Institut Injil Indonesia, Malang-Batu), Edisi 2000/2004. Dan saat ini menjadi bahan kuliah di Institut Injil Indonesia untuk mata kuliah Eksposisi Perjanjian Lama. 
ini adalah pertama: adanya repetisi (pengulangan) kata kerja bentuk imperatif dalam ayat 2, 4 yang berfungsi sebagai penekanan (emphasis) utama dalam kedua ayat ini. Kedua: adanya pengulangan sejajar antara akhiran ganti orang ke-2 tunggal maskulin dengan kata ganti orang pertama jamak, yang berfungsi sebagai penjelasan stikos pertama kepada stikos kedua dalam ayat 3. Ketiga: adalah pemakaian kata ki yang berarti "sebab" atau "bahwa," dihubungkan dengan garis maqef sebagai satu kesatuan penjelasan yang utuh dari ayat $5 .^{2}$ Karena itu kerangka utama dari Mazmur 100:1-5 adalah:

1. Pendahuluan dan judul (ay. 1)

2. Panggilan untuk menyembah TUHAN (ay. 2,4)

3. Panggilan untuk mengakui TUHAN (ay. 3)

4. Alasan untuk menyembah TUHAN (ay. 5)

Berangkat dari kerangka utama ini, maka dapatlah ditemukan suatu garis besar yang lengkap dari Mazmur 100:1-5 ini.

Dengan demikian garis besar dari Mazmur 100:1-5 adalah sebagai berikut.

I. Pendahuluan dan judul (ay. 1)

II. Panggilan untuk menyembah TUHAN (ay. 2, 4)
A. Layanilah TUHAN dengan sukacita (ay. 2a)
B. Datanglah ke hadapan-Nya dengan sukacita (2b)
C. Masuklah ke pintu gerbang-Nya (ay. 4a)
D. Bersyukurlah kepada-Nya (ay. 4b)
E. Pujilah nama-Nya (ay. 4c)

III. Panggilan untuk mengakui TUHAN (ay. 3)
A. Penegasan panggilan (ay. 3a)
B. TUHANlah Allah (ay. 3b)
C. Dialah yang menjadikan kita (ay. 3c)
D. Punya Dialah kita (ay. 3d)
E. Umat-Nya dan kawanan domba gembalaan-Nya (ay. 3e)

IV. Alasan untuk menyembah TUHAN (ay. 5)
A. TUHAN itu baik (ay. 5a)
B. Kasih setia-Nya untuk selama-lamanya (ay. 5b)
C. Kesetiaan-Nya tetap turun-temurun (ay. 5c)

2 Dalam hal ini, VanGemeren melihat dengan sangat jelas pembagian kerangka utama dari Mazmur 100:1-5 ini. Menurutnya Mazmur 100:1-5 memiliki struktur yang sangat simpel dan memiliki tema utama, yakni: 1. Panggilan untuk bersyukur (ay. 1, 2, 4) dan 2. Sukacita karena perjanjian kasih (ay. 3, 5) yang diikat oleh satu kesatuan pujian syukur oleh kata kerja bentuk imperatif sebagai tekanan utamanya. Willem A. VanGemeren, The Expositor's Bible Commentary. Vol. V (Michigan, Grand Rapids: Zondervan Publishing House, 1991), 638. 
Sedangkan struktur dari Mazmur 100:1-5 adalah sebagai berikut.

STRUKTUR MAZMUR 100:1-5

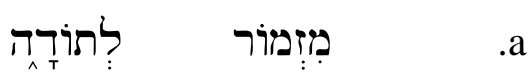

(1)

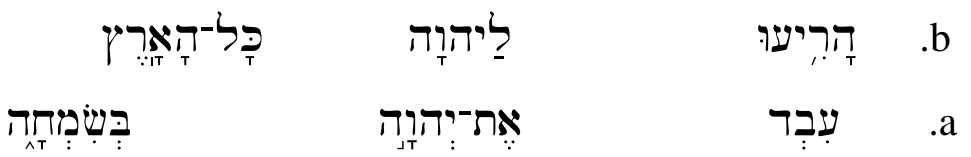

(2)

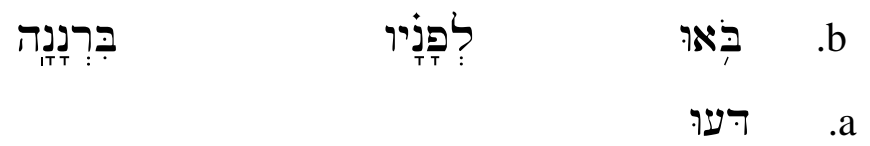

(3)

\begin{tabular}{|c|c|c|c|c|}
\hline \multirow{2}{*}{\multicolumn{2}{|c|}{ אלَה }} & הוּא & ירוָה & כָים \\
\hline & & עָעָנָּוּ & הוּאוא & \\
\hline & אגֵחוזנ: & וִלוֹ & & \\
\hline 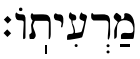 & וְנְצאן & עַפִֹ & & \\
\hline בְּת & & 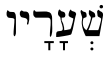 & & \\
\hline
\end{tabular}

(4)

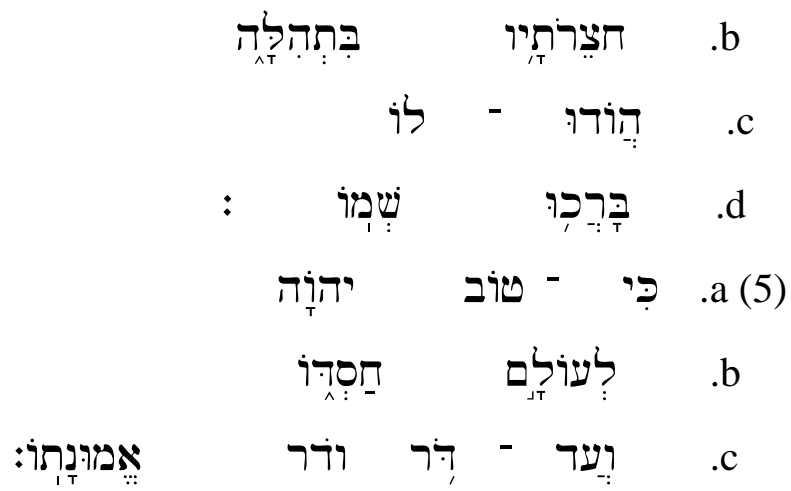

B. Bentuk Literatur (genre) Mazmur 100:1-5

Hal yang menguntungkan dalam proses penyelidikan terhadap 
bentuk literatur dari Mazmur 100:1-5, adalah disebutnya bentuk literatur yang paling menonjol, yaitu "persembahan syukur" atau תרוֹ (tôdâ). Kata tôdâ merupakan pembentukan dari kata "yada" (ידָה) yang berarti "pengakuan", "penyembahan", dan "ucapan terima kasih."3 Kata tôdâ ditulis dalam Perjanjian Lama sebanyak 30 kali. ${ }^{4}$ Dalam penyelidikan terhadap kata tôdâ ini, Leslie C. Allen menemukan beberapa komponen utama dari bentuk literatur Mazmur 100:1-5 ini, yang menurutnya dapat dicirikan sebagai berikut. ${ }^{5}$

1. Ekspresi dari penyerahan diri dan pengakuan akan kuasa Allah

2. Model dan bentuk dari tata cara ibadah yang digunakan dengan berbalas-balasan dalam bentuk pujian

3. Sebagai persembahan syukur yang dinyanyikan dengan iringan musik oleh satu orang atau kelompok

4. Sebagai ucapan syukur dalam bentuk doa syafaat yang tertata dalam liturgi ibadah

5. Sebagai nyanyian pembukaan dan nyanyian arak-arakan menuju pintu gerbang bait Allah

Dengan demikian Mazmur 100:1-5 mempunyai bentuk literatur yang khas yaitu tôdâ yang diucapkan dalam ayat 1 dan berfungsi sebagai judul dari Mazmur ini. Pengertian tôdâ secara khusus memaparkan tentang persembahan khusus kepada TUHAN dalam bentuk pujian yang dinyanyikan bersama dalam arakan menuju bait Allah, tetapi juga sebagai lagu pujian pembukaan dalam ibadah yang diiringi oleh musik dan tarian.

\section{Kedudukan Kehidupan Tôdâ}

Tôdâ adalah suatu persembahan syukur kepada TUHAN yang dinyanyikan dalam ibadah. ${ }^{6}$ Persembahan syukur ini dinyanyikan bersamasama dengan diiringi oleh permainan musik, yang mana menyatakan tentang kekuatan, kebaikan, dan pemeliharaan TUHAN Allah yang juga

3 Ralph H. Alexander, ידָ dalam R. Laird Harris (ed), Theological Wordbook of The Old Testament. Vol. I (Chicago: Moody Press, 1980), 364-365.

4 G. Meter, ידָה dalam G. Johannes Botterweck \& H. Ringgren, Theological Dictionary of The Old Testament. Vol. V (Grand Rapids, Michigan: Wm. B. Eerdmans Publishing Company, 1986), 427.

Leslie C. Allen, ידָה dalam Willem A. VanGemeren (ed), Dictionary of Old Testament Theology \& Exegesis. Vol. II (Michigan, Grand Rapids: Zondervan Publishing House, 1997), 406.

C.N. Dilman, “Thank; Thankful (ness); Thanksgiving," dalam Geoffrey W. Bromiley, The International Standart Bible Encyclopedia. Vol. IV (Michigan, Grand Rapids: Wm.B. Eerdmans Publishing Co., 1988), 822-823. 
nampak dalam kemahakuasaan-Nya. ${ }^{7}$

Dalam literatur Mesir kuno, ada terdapat literatur yang dapat dikaitkan dengan nyanyian korban syukur, yakni korban syukur dalam bentuk pujian yang dinyanyikan secara individu ataupun secara berkelompok untuk memuja keberadaan para dewa yang telah memberikan perlindungan terhadap Mesir, mulai dari raja sampai rakyat jelata, dan juga kepada keadaan kota yang aman. ${ }^{8}$

Sedangkan dalam literatur Akadian, tôdâ dipakai sebagai doa doxology yang mengakui perbuatan para ilah-ilah di tengah-tengah manusia, tetapi juga menunjukkan suatu hubungan yang akrab antara manusia dengan para ilah-ilah tersebut. ${ }^{9}$ Dengan demikian, seseorang dapat menemukan kesamaan dan juga perbedaan dari kedua bentuk literatur ini.

\section{Tujuan dan Fungsi Tôdâ dalam Mazmur 100:1-5}

Fungsi utama tôdâ adalah sebagai persembahan syukur kepada Allah, karena perbuatan-Nya yang ajaib. Namun dalam Mazmur 100:1-5 ini, secara spesifik lebih menekankan bentuk persembahan syukur sebagai "pengakuan" akan kekuasaan TUHAN yang nyata dalam pemeliharaan-Nya kepada umat kepunyaan-Nya, ${ }^{10}$ tetapi juga sebagai suatu pujian liturgia dalam bait Allah yang dinyanyikan bersama-sama ketika memasuki pintu

\footnotetext{
$7 \quad$ Ibid., 822.

8 Egyptian has no words that clearly mean "(offer) thanksgiving" or "Prayer of thanksgiving", etc. Several words and phrases and attitudes suggested by the determinatives convey insufficient information. In a double procession comprising twentyfour persons, for example, him is used to describe the action of a single individual participant; one may reasonably ask whether his attitude is really more thankful than that of the others. A parallel text uses the two other expressions that the Wbas translates as "thank" hsyR' 15 and dw3-ntr. The formation of these two expressions is interesting. According to the Wbas "give thanks for something" is thus expressed by saying "praise Re (or god) for something". It is important to note that these expressions can have both human beings and gods as subject, and that thanks can be given for persons, pharaoh cities, etc. In a dedication inscription from Denderah, Hathor thanks the Pharaoh, her beloved son, as well as the city for the temple and its precinct; i.e., she "praise Re" for the pharaoh and the city.

$9 \quad$ Ibid., 430.

10 Kitab Mazmur dibagi menjadi 5 bagian utama, yaitu:

1. Pujian Penyembahan (Mzm. 1-41:13)

2. Pujian karena keajaiban Tuhan (Mzm. 42-72:19)

3. Penyembahan bersaut-sautan (Mzm. 73-89:52)

4. Penyembahan dengan berkhitmat (Mzm. 90-106:48)

5. Penyembahan yang sempurna (Mzm 107-150:6); Bnd. Irving L. Jensen, Jensen's Survey of the Old Testament (Chicago: Moody Press, 1978), 280.
} 
utama bait Allah. ${ }^{11}$ Hal ini didukung oleh posisi Mazmur 100:1-5, yaitu sebagai bagian dari penyembahan yang dinaikkan kepada Allah dengan khidmat. $^{12}$

Bagi orang Israel, Mazmur 100:1-5 merupakan Mazmur pengungkapan sukacita ibadah, dimana orang Israel dapat merasakan suatu hubungan yang harmonis antara Allah YHWH dengan mereka yang ditandai dengan perjanjian sebagai pengikat persekutuan mereka dengan Allah, ${ }^{13}$ tetapi juga sebagai pengakuan secara individual tentang kenyataan pemeliharaan Allah. ${ }^{14}$

\section{EXEGESE MAZMUR 100:1-5}

\section{A. Pendahuluan dan Judul}

Dalam analisa struktur teks, telah ditentukan bahwa Mazmur 100:15 dimulai dengan suatu judul dan sekaligus juga sebagai pendahuluan dari keseluruhan Mazmur 100:1-5 ini. Pendahuluan dan judul dari Mazmur

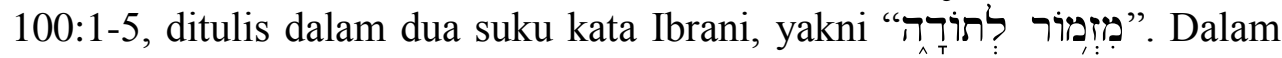
NASB, kedua kata ini diterjemahkan menjadi "A psalm for thanksgiving", hal yang sama juga diikuti oleh NRSV. Sedangkan LAI menerjemahkannya menjadi "Mazmur untuk korban syukur". Dalam hal ini LAI mengikuti terjemahan yang diusulkan oleh John Joseph Owens dalam bukunya "Analytical Key to the Old Testament" sebagai "a psalm for the thank offering." 15 Maria Claire Barth dan B.A. Pareira, tidak melihat adanya suatu kesimpangan dari terjemahan ini, keduanya lebih memilih jalan tengah dengan mengusulkan terjemahan yang bersifat lebih akomodatif dari semua terjemahan di atas dengan terjemahan "Mazmur untuk mempersiapkan pujian."16 Sehingga kesimpulannya adalah bahwa apapun bentuk terjemahan yang digunakan, semuanya menunjuk tentang suatu judul yang lebih kena-mengena dengan ibadah ucapan syukur.

Kata פִ ביזמוֹר dalam bentuk nominatif maskulin tunggal artinya adalah

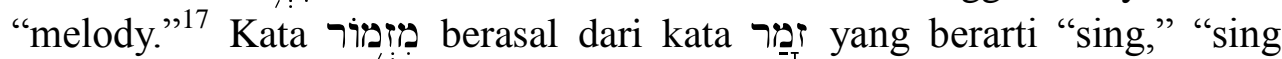

\footnotetext{
11 Meyer, hdy dalam Theological Dictionary..., 428.

Jensen, Jensen's Survey..., 280.

VanGemeren, The Expositor's Bible..., 638.

Ibid., 639.

15 John Joseph Owens, Analytical Key to the Old Testament. Vol. III. (Michigan:Grand Rapids, 1991), 433.

16 Marie Claire Barth \& B.A. Pareira, Tafsiran Kitab Mazmur 73-150 (Jakarta: BPK Gunung Mulia, 1997), 224.

17 Francis Brown, The Brown-Driver-Briggs Hebrew and English Lexicon
} 
praise," dan "make music."18 Dalam konyugasi piel, kata ini memiliki kesamaan dengan "zamaru" dalam literatur Akadian, yang berarti "to sing,

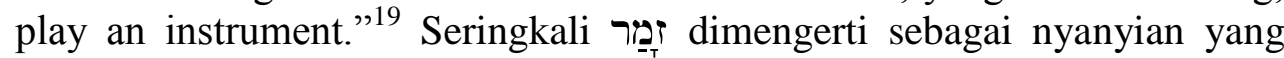
diiringi beragam alat musik. ${ }^{20}$ Tetapi juga dinyanyikan dengan terangkat, ${ }^{21}$ bahkan dengan tari-tarian. $^{22}$

Kata תרדָה dalam bentuk nominatif feminim tunggal, artinya "thank offering." 23 Dalam penelitian secara biblical, Carl F. Keil, mengatakan bahwa " tôdâ" adalah dasar sekaligus jantung dari Mazmur $100 .{ }^{24}$ Kata ini telah memberikan pengertian bahwa Mazmur 100 sering dinyanyikan sebagai nyanyian pembukaan ibadah atau nyanyian perarakan masuk bait suci. $^{25}$ Dalam kesimpulannya, Marvin E. Tate mengatakan bahwa pengertian dasar "tôdâ" adalah korban persembahan di dalam upacaraupacara syukur yang menjadi lagu pujian. ${ }^{26}$

\section{B. Panggilan untuk Menyembah TUHAN (ay. 2, 4)}

(Hendrickson: Publisher, 1992), 274.

18 Wolf, dalam Theological Wordbook..., 245.

19 Wolf, זָזָר dalam Theological Wordbook..., 245.

20 Dalam hal ini, Wolf menyatakan: "Sometimes Zamar is directly linked with a musical instrument. The Ly (Ps. 71:22), the ten stringed lyre (Ps. 33:2; 144:9), the harp (Ps. 98:5) and the tambourine (Ps. 149:4), are all used to "make music" in praising the Lord. Wolf. Ibid.

21 Ibid.

$22 \quad$ Ibid

$23 \quad$ Owens, Analytical Key..., 433.

24 C.F. Keil \& F. Delitzsch, Commentary On The Old Testament, Vol. V Psalm (Grand Rapids: Wm.B. Eermands Publishing Co., 1984), 104.

25 Barth \& B.A. Pareira, Tafsiran Kitab Mazmur..., 224.

26 The word hdwt (also in v 4) can mean either "thanksgiving praise" or "confession" (Josh 7:19; Ezra 10:11). The root meaning of the verb hdy in hiphil is "to confess/declare/praise": a point strongly emphasized by C. Westermann (Praise and Lament, 25-35), who notes that there is no word in Hebrew which properly means "to thank," praise being either declarative, referring to what God has done, or descriptive, referring to what he characteristically does. The word hdwt can also mean a "thank offering" or "thank sacrifice" (see the summary in Crüsemann, Studien zur Formgeschichte, 282-84). The hdwt probably originally was a sacrifice offered in a thanksgiving ceremony and then became a "song of praise" to accompany the sacrifice (Gerstenberger, Psalms, 14). I have retained the traditional "thanksgiving," but the double meaning of the word should be remembered. Fortunately, the English "for thanksgiving" has a double nuance of "praise" and the "act of giving thanks" which could involve a worship service and is appropriate for the title (cf. Howard, Structure, 130). hdwt appears in no other title of a psalm. Marvin E. Tate, Word Biblical Commentary. Vol. II (Michigan, Grand Rapids: Baker Book House, 1969), 382. 
Panggilan untuk menyembah TUHAN nampak dalam penggunaan bentuk imperatif terhadap beberapa kata kerja dalam teks ini. Namun hanya beberapa istilah saja yang penulis uraikan, mengingat istilah-istilah tersebut bagi penulis dapat menjawab pembahasan dalam poin ini.

\section{1. עִבְדרוּי}

Kata ini diterjemahkan menjadi "serve,"27 terjemahan yang sama diikuti juga oleh NIV, NASB, dan NRSV. LAI menerjemahkan kata ini dengan "beribadah". Kata עיברבד berasal dari kata kerja עבד yang berarti "hamba" atau "pekerja," 28 yang mana "hamba" atau "pekerja" tersebut tidak memiliki hak tetapi kewajiban, dalam artian bahwa pekerjaan "hamba" bukan sebagai objek tetapi subjek. ${ }^{29}$ Dalam konteks Mazmur 100:1-5, kata ini dalam bentuk qal imperatif orang kedua jamak. Pengertian imperatif ini memberi pengertian bahwa kata tersebut telah menjadi suatu kalimat perintah atau bahkan perintah saja yang dipertegas dan menyatakan panggilan yang sungguh-sungguh, tetapi juga merupakan keharusan yang mendesak untuk dilaksanakan oleh objek panggilan. ${ }^{30}$ Walter C. Kaiser mengatakan bahwa kata ini juga dapat diartikan sebagai "pengabdian" kepada raja, sebagai wujud dari ketaklukan" untuk melayani sebagai hamba atau pelayan. ${ }^{31}$ Sehingga nampak jelas bahwa melayani sebagai hamba kepada TUHAN merupakan pekerjaan yang harus dan sangat mendesak untuk dikerjakan dengan penuh tanggung jawab. Dengan demikian gambaran TUHAN sebagai Raja yang harus dilayani ada dibalik seruan ini. $^{32}$

\section{2. ברואוּ}

Kata ini ditulis dalam bentuk qal imperatif orang kedua maskulin jamak, yang diterjemahkan menjadi "come." "33 Terjemahan yang sama

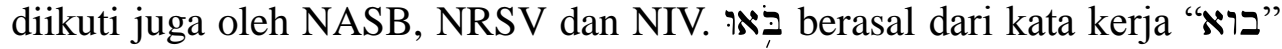
yang berarti "come in." 34 Elmer A. Martens mengusulkan terjemahan yang

\footnotetext{
27 Owens, Analytical Key..., 433.

28 Brown, The Brown-Driver-Briggs ..., 712-713.

29 Ibid., 713.

30 George Herbert Livingston, The Wesleyan Bible Commentary. Vol. II (Michigan, Grand Rapids: Baker Book House, 1969), 382.

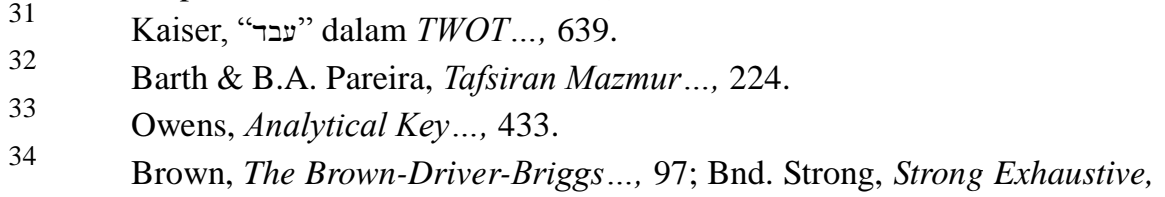


lain, yakni "go in" atau "enter." 35 Kata "בואי" ditulis dalam Perjanjian Lama sebanyak 2.570 kali dan lebih banyak digunakan kepada para perantau yang kembali ke kampung halaman, ${ }^{36}$ tetapi juga sebagai ajakan Allah kepada umat-Nya untuk kembali kepada perjanjian. ${ }^{37}$ Dengan dua pengertian di atas, maka istilah בוא di sini, tidak diperuntukkan khusus kepada Israel saja tetapi juga sebagai ajakan langsung kepada segala bangsa,

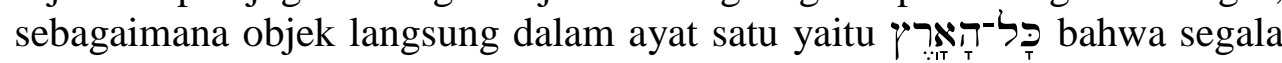
bangsa akan tergabung bersama-sama dalam nyanyian pujian syukur kepada Allah, tanpa ada perbedaan dan diskriminasi. Dalam hal ini keselamatan telah bersifat universal, yakni tidak diperuntukkan kepada Israel saja. Hal sama diungkapkan oleh George Herbert Livingston sebagai berikut.

Far from being exclusive and racist in its attitude, this poem exhort all lands to come into the temple courts and join in making a joyful noise. In the presence of God there is no room for discrimination; rather, a realization of his universal power begets a concern that all his children be include within his fold. ${ }^{38}$

Namun, jika yang dimaksud di sini adalah bangsa Israel yang dipanggil untuk bersukacita, maka istilah Ibrani yang lebih cocok adalah בוא "return" dan bukan בוּיב "come."39 Maka jelaslah bahwa " בוא merupakan ajakan langsung yang mendesak untuk memuji TUHAN, dari TUHAN kepada seluruh bangsa di dunia.

Dengan demikian kedua istilah yakni עבר d בּאו dan memberikan penjelasan bahwa panggilan secara tegas untuk menyembah TUHAN adalah ajakan Allah kepada seluruh bangsa untuk bersama-sama menjadi pelayan-pelayan yang mengangkat puji-pujian dalam rumah Allah untuk memasyurkan kebesaran TUHAN Allah. ${ }^{40}$

\section{Panggilan untuk Menyembah TUHAN Allah}

Ajakan dalam Mazmur 100:1-5 kepada seluruh bangsa di dunia untuk mengakui TUHAN Allah nampak di dalam penggunaan istilah-istilah

19.

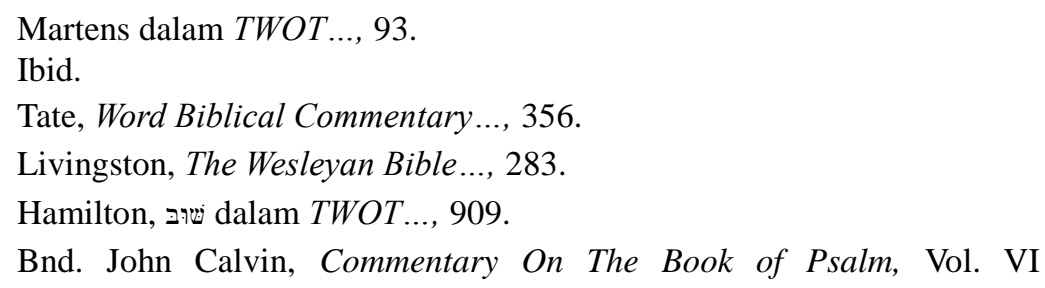


yang berkaitan dengan TUHAN sebagai subjek dan bangsa-bangsa sebagai objek, namun keduanya tetap terikat dimana TUHAN sebagai pemilik. ${ }^{41}$ Istilah-istilah yang dimaksud adalah sebagai berikut.

\section{Ketahuilah bahwa Dialah TUHAN Allah"}

Marvin E. Tate menerjemahkan kalimat ini berdasarkan terjemahan tradisional menjadi "know that Yahweh is God." ${ }^{2}$ _Melalui kalimat ini, Tate memberikan dua pengertian yang sangat mendasar yakni, pertama: bahwa hanya TUHAN yang patut disembah. Kedua, adalah jaminan bagi orang percaya bahwa TUHANlah Allah. Dia mengatakan bahwa pengulangan kata הוּא 3, merupakan penekanan yang perlu diperhatikan bahwa itulah petunjuk utama tentang TUHAN yang adalah TUHAN itu. ${ }^{43}$ Dalam sisi lain, pemakaian bentuk imperatif dari kata דיע pada awal kalimat memberikan pengertian bahwa bangsa-bangsa yang dipanggil untuk menyembah TUHAN itu juga harus mengakui keberadaan

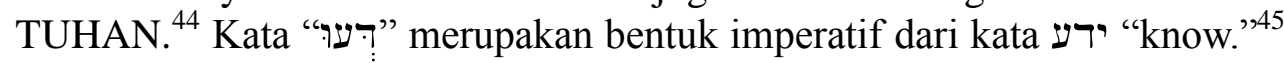
Kata ini dalam penggunaannya paralel dengan hikmat atau menunjukkan

Ibid.
42 Tate, Word Biblical Commentary..., 533.
Traditional, "Know that Yahweh is God" (lit., "know that Yahweh, he
[indeed] is God") is used in the sense of a summons (1) to learn that Yahweh is God in
terms of the "self-involvement in all the demands and responsibilities which the Lordship
of Yahweh implies " (Anderson, II, 699), or (2) to be assured, to have no doubt, that
Yahweh is God (Barnes, II, 472). However, the context seems to favor the idea of
"acknowledge/ recognize/confess" (as, e.g., Kraus, II, 855; NJV; REB). V 3. seems to be a
form of a "recognition formula," which W. Zimmerli has delineated in the Book of
Ezekiel, taking his case from the repeated use of the statement "And you (or "you" plural,
or "they") shall know that I am Yahweh" (in "Knowledge of God according to the Book of
Ezekiel," in I Am Yahweh, tr. D. W. Stott [Atlanta:John Knox, (1954) 1982] 30; a full list of
the passages in Ezekiel is found on 143, n. 5). The formulaic saying also appears in other
contexts (e.g., 1 Kgs 20:13, 28; Exod 6:6-9; 8:20; 16:12; 29:43-46). The freer formulation
"know that Yahweh is God" ( $\mu$ yhla awh hwhy yk w[d) appears to be Deuteronomic
(Zimmerli, 51-52; cf. Deut 4:35, 39; 1 Kgs 8:60; 2 Kgs 19:19) and includes Ps 100:3
(Zimmerli, 53). The formula appears in varied forms in other contexts as well (Zimmerli,
53-63). The recognition of Yahweh is an acknowledgment of his identity in terms of his
actions.
actions.

The pronoun awh ("he") is added for emphasis (see GKC 141gh; cf. Deut 4:35; 7:9; Josh 4:18; $1 \mathrm{Kgs}$ 18:39): "know that Yahweh, he is God," or even, "Yahweh alone is God" (Rogerson and McKay, II, 230, with special emphasis on 1 Kgs 18:39); Tate, Word Biblical Commentary..., 533.

$44 \quad$ VanGemeren, The Expositor's Bible..., 693.

Owens, Analytical Key..., 433. 
orang yang bijaksana. ${ }^{46}$ Tetapi secara lebih khusus "yada" menunjukkan kepada pengetahuan tentang Allah secara komprehensif, ${ }^{47}$ bahwa sesungguhnya hanya TUHAN itu Allah dan tidak ada yang lain, he alone is God, and there is none beside him. ${ }^{48}$ Livingston menyebut pemahaman ini sebagai pengakuan kepada Allah yang benar dan ke-Tuhanan Allah yang agung. With firm conviction he was able to declare that the only true God in the universe was called Jehovah, the special covenant name that Israel applied to deity. ${ }^{49}$

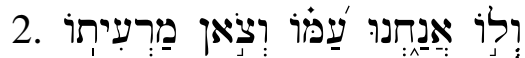

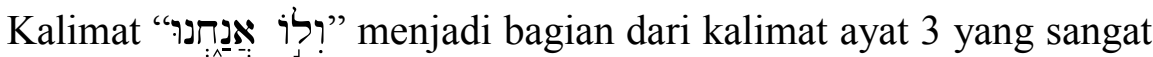
terkenal dalam Mazmur 100 ini. Selain mengakibatkan banyak pertanyaan, tetapi juga memberikan stimulasi bagi para penafsir untuk mengadakan penelitian lebih lanjut dari kalimat ini. Kalimat ini diterjemahkan oleh LAI menjadi "dan punya Dialah kita". Agaknya LAI mengikuti terjemahan yang diusulkan oleh "qere" dalam BHS. Namun BHS pulalah terdapat "ketiv"

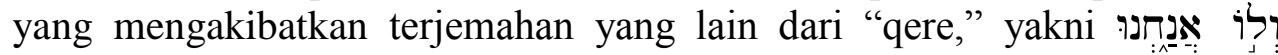
yang berarti "dan bukan kita (yang menjadikan diri kita)." Dalam hal ini Marvin E. Tate mengatakan,

This statement poses a famous question in interpretation. The ketiv of MT reads wnjna alw, "and not we (ourselves)," but the qere reads wnja wlw, "and we are his." LXX, Symm., and Syr. suggest the "and not we ourselves" reading, but the "and we are his" has good support with some mss, Aquila, Jerome, and Targum (and cf. Ps 95:7; esp. note the variant in BHS: cf. Ps 79:13). Also, the Masoretic tradition reckons some fifteen passages in which al ("not") is written but which should be read as is wl. ${ }^{50}$

Dalam pengamatannya dalam dua terjemahan, yakni "qere" dan "ketiv" terhadap kalimat ini, maka John Calvin lebih memilih "qere", yaitu

46

It appears parallel with wisdom (hokma) and understanding (tebuna), instruction (musar), and law (tora). Wisdom is used in series with "science" (magda) Dan. 1:4 and "yada" is the contemplative perception of the wise man. Jack P. Lewis, ידע dalam TWOT..., 36 .

Ibid. Abingdon Press, 1978), 534.

George Arthur Buttrick, The Interpreter's Bible. Vol. IV (Nashville:

$49 \quad$ Livingston, The Wesleyan Bible..., 382.

$50 \quad$ Tate, Word Biblical Commentary..., 533; "To him," Brown, The BrownDriver-Briggs..., 520. 
"Dan punya Dialah kita." ${ }^{, 5}$ Penerimaan terhadap terjemahan ini sangat beralasan karena dalam ayat 3a tidak mempertentangkan antara TUHAN dan Israel, melainkan dengan dewa-dewa. ${ }^{52}$

Dengan penerimaan terhadap terjemahan "qere", maka perhatian harus ditujukan kepada preposisi ?ִ pada kalimat pengan mendapat

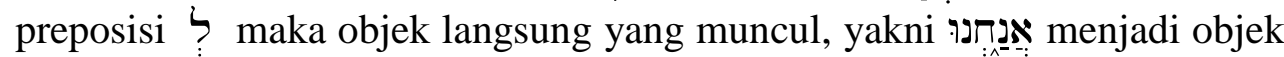
yang dimiliki oleh subjek dalam kalimat ini, yaitu is yang terbentuk dari akhiran ganti orang ke-3 tunggal maskulin dengan preposisi ל. ${ }^{53}$ Fungsi ? di sini adalah "le" kepemilikan atau genetative possessive lamed, ${ }^{54}$ maka dengan mendapat genetative possessive lamed, אגנחנו: harus menjadi milik dan bagian integral dari לו לו.

Dari pemahaman di atas nampaklah "umat kepunyaan Allah" dipanggil untuk mengakui keberadaan TUHAN Allah. Panggilan kepada

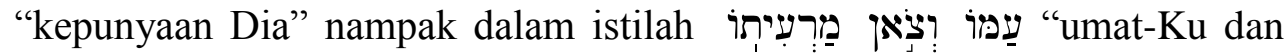
domba gembalaan-Ku" dalam hal ini, kalimat tersebut menyatakan bahwa Allah mengasihi umat pilihan-Nya yang telah dituntun-Nya dengan kasih yang kekal masuk ke dalam suatu pujian penyembahan yang dinyanyikan bersama-sama dalam Bait Allah. Dalam Hal ini H.C. Leupold mengatakan,

"His people and the sheep of His pasture" this statement is meaningful even if one does not resort to the idea that it was sung by the national group of worshipers as they came streaming through the temple doors and into the sanctuary, giving the impression that they were like a flock which was following the shepherd's call. What a rare privilege that was to be singled out from among all the nations on the face of the earth to be in very special sense God's people and His people! No man weighs this fact aright can remain cold and unresponsive. ${ }^{55}$

The Hebrew text has a keri, which is ולו אִגְנוּ "and we are his", instead of

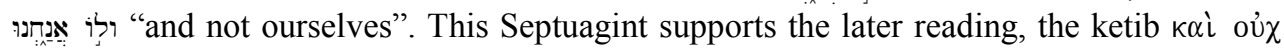
$\dot{\eta} \mu \in \hat{i} \varsigma$, "and not we ourselves", in which it is followed by Syriac and Vulgate versions. Jerome agrees with the keri, Ipse fecit nos, et ipsius sumus; and so does the Chaldee. "I am persuaded," says Lowth, in Merrick's Annotations, "that the Masoretical correction, ולו (and we are his), is right: the construction and parallelism both favour it." Calvin, Commentary On The Book..., 85.

$52 \quad$ Barth \& B.A. Pareira, Tafsiran Mazmur..., 223.

53 Owens, Analytical Key..., 433.

54 Yoshiaki Hattori, Langkah-langkah Praktis Dalam Eksegese Perjanjian Lama (Batu: I.I.I., 1989), 22-23.

55 H.C. Leupold, Exposition of Psalm (Michigan: Grand Rapids: Baker Book House, 1969), 700. 


\section{Alasan untuk Menyembah TUHAN}

Meskipun dalam bagian ini ada beberapa alasan yang dikemukakan untuk menyembah TUHAN, namun penulis hanya tertarik membahas istilah "Kasih setia-Nya untuk selama-lamanya" dalam ayat 5 dari Mazmur 100:1-5 ini, karena dalam pengamatan penulis istilah "kasih setia-Nya" lebih dominan untuk dijadikan alasan mengapa harus menyembah TUHAN.

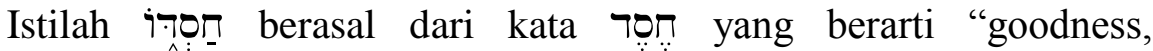
kindness." $" 56$ Dalam penggunaan pada umumnya kata ini diterjemahkan secara bervariasi ke dalam bahasa Inggris. KJV menerjemahkan menjadi "steadfast love," NIV "love," dan NASB menjadi "loving kindness." LXX sering memakai istilah ini dengan "eleos," "loyal covenantal love." 58 Dalam terjemahan modern untuk semua variasi ini, yang sering digunakan untuk kata ini adalah "grace.",59

חסֶ selalu juga menggambarkan suatu perbuatan kasih diantara dua pihak yang terikat oleh perjanjian, dengan tindakan-tindakan seperti kesetiaan, kemuarahan, kebaikan. ${ }^{60}$ Dalam hubungan antara Allah dengan manusia semua tindakan-tindakan tersebut hanya terdapat pada diri Allah, atau menunjukkan bahwa Allah adalah sumber kasih itu sendiri. "The first of these indicates that God is the source of all love." ${ }^{\prime 61}$ Dan kasih itu juga adalah hakikat Allah. ${ }^{62}$ Sehingga dalam menyatakan kasih-Nya kepada manusia, Allah digambarkan sebagai gembala yang memelihara dombadombanya. Selanjutnya, Thomas E. McComiskey mengomentari kata ini demikian:

" "Ror" (khesed; NIV, "Mercy" has the basic meaning of "kindness" Gen. 19:19; 40:14, Ruth 3:10, Josh. 2:12-14). Kindness was expected between partners in certain previously existing relationships such as marriage (Gen. 20:13) and friendship (1Sam. 20:8). Hesed is also an attribute of God and is basic to his act of redemption, and the demonstration of hesed on God's part establish a hesed relationship in which God expects an ethical response from

\footnotetext{
56 Brown, The Brown-Driver-Briggs..., 338.

57 Bnd. Merril F. Unger \& William Whiter, Nelson's Expository Dictionary of The Old Testament (Nashville: Thomas Nelson Publisher, 1980), 323.

58 Harris, dalam TWOT..., 305.

$59 \quad$ Ibid

60 Walter A. Elwell, Evangelical Ditionary of Theology (Grand Rapids: Baker Book House, 1985), 657.

61 Ibid.

62 God is not only the source of love, but love itself, S.S. Samalley, Word Biblical Commentary: 1,2,3 John (Waco, Texas: Word Book Publisher, 1984), 239.
} 
man as man's reciprocal responsibility. The ethical expects of these are peculiarly evident in the prophets. They make clear that if one fails to show hesed, he has broken the terms of the covenant; and since the covenant is the vehicle for obtaining God's hesed, the covenant breaker has removed himself from any right to obtain it. ${ }^{63}$

Dengan demikian, apabila חָסִ dalam ayat 5 ini dipergunakan dalam hubungan dengan Allah, maka inisiatif kasih itu hanya pada Allah saja. Hanya Allah yang mampu mengasihi manusia dengan kasih sempurna, dan terikat dalam suatu perjanjian kasih. ${ }^{64}$

\section{KESIMPULAN}

Mazmur 100 dikategorikan dalam jenis mazmur korban ucapan syukur yang terdiri dari dua bait yakni: bait pertama ayat 1-3, dan bait kedua ayat 4-5 masing-masing bait terdiri dari dua undangan dan alasan yang kuat mengapa harus menyembah TUHAN. Karena hubungan kedua bait sangat erat, maka mazmur ini sering dinyanyikan dengan berbalasbalasan dalam suatu jemaah atau sebagai nyanyian perarakan masuk ke dalam bait suci. Tetapi juga sebagai pengakuan iman kepada Allah sebagai Raja yang harus dilayani dan dimuliakan.

Pesan utama dari Mazmur 100 adalah bahwa keselamatan tidak lagi dikhususkan kepada Israel saja melainkan keselamatan itu adalah bersifat universal, dimana tidak ada lagi diskriminasi dan pengurangan peran dari pihak lain untuk memuji dan menyembah TUHAN terhadap orang-orang dari segala bangsa di dunia yang telah ditebus TUHAN. Dengan demikian di dalam Mazmur 100 ini, Israel melihat hubungan TUHAN dengan bangsa-bangsa secara baru dan karena itu Israel juga harus memperbaharui pula. Karena hanya TUHAN-lah Allah dan tidak ada yang lain, maka hanya ada satu umat dan satu ibadah.

\section{KEPUSTAKAAN}

Thomas E. McComiskey, The Expositor's Bibli Commentary. Vol. VII (Michigan, Grand Rapids: Zondervan Publishing House, 1985), 437.

64 The word "חסד" (khesed) is a "covenant love," it presupposes right and obligation and demands a favorable attitude from both parties to a relationship. Freedman Lundbon, "Hanan" dalam G.J. Booterweck \& H. Ringgren (ed), Theological Dictionary of The New Testament, Vol. V (Grand Rapids: Wm.B. Eerdmans Publishing Co., 1986), 25. 
Barth, Marie Claire \& Pareira, B.A.

1997 Tafsiran Kitab Mazmur 73-150. Jakarta: BPK Gunung Mulia.

Botterweck, G. Johannes \& Ringgren, H. (ed)

1986 Theological Dictionary of The Old Testament. Vol. V. Grand Rapids, Michigan: Wm. B. Eerdmans Publishing Company.

1986 Theological Dictionary of The New Testament, Vol. V. Grand Rapids: Wm.B. Eerdmans Publishing Co.

Bromiley, Geoffrey W. (ed)

1988 The International Standart Bible Encyclopedia. Vol. IV. Michigan, Grand Rapids: Wm.B. Eerdmans Publishing Co.

Brown, Francis (ed)

1992 The Brown-Driver-Briggs Hebrew and English Lexicon. Michigan, Grand Rapids: Hendrickson Publisher.

Buttrick, George Arthur

1978 The Interpreter's Bible, Vol. IV. Nashville: Abingdon Press.

Calvin, John

1979 Commentary On The Book of Psalm. Vol. VI. Michigan, Grand Rapids: Baker Book House.

Elwell, Walter A.

1985 Evangelical Ditionary of Theology. Grand Rapids: Baker Book House.

Harris, R. Laird (ed)

1980 Theological Wordbook of The Old Testament. Vol. I. Chicago: Moody Press.

Hattori, Yoshiaki

1989 Langkah-langkah Parktis Dalam Eksegese Perjanjian Lama. Batu: I.I.I.

Jensen, Irving L.

1978 Jensen's Survey of the Old Testament. Chicago: Moody Press.

Keil, C.F. \& Delitzsch, F.

1984 Commentary On The Old Testament, Vol. V Psalm. Grand Rapids: Wm.B. Eermands Publishing Co.

Leupold, H.C.

1969 Exposition of Psalm. Michigan: Grand Rapids: Baker Book House.

Livingston, George Herbert

1969 The Wesleyan Bible Commentary. Vol. II. Michigan, Grand Rapids: Baker Book House.

McComiskey, Thomas E. 
1985 The Expositor's Bibli Commentary. Vol. VII. Michigan, Grand Rapids: Zondervan Publishing House.

Owens, John Joseph

1991 Analytical Key to the Old Testament. Vol. III. Michigan, Grand Rapids: Baker Book House.

Samalley, S.S.

1984 Word Biblical Commentary: 1,2,3 John. Waco, Texas: Word Book Publisher.

Tate, Marvin E.

1969 Word Biblical Commentary. Vol. II. Michigan, Grand Rapids: Baker Book House.

Unger, Merril F. \& Whiter, William

1980 Nelson's Expository Dictionary of The Old Testament. Nashville: Thomas Nelson Publisher.

VanGemeren, Willem A.

1991 The Expositor's Bible Commentary. Vol. V. Michigan, Grand Rapids: Zondervan Publishing House.

1997 Dictionary of Old Testament Theology \& Exegesis. Vol. II. Michigan, Grand Rapids: Zondervan Publishing House. 